\title{
Geology
}

\section{Toba ash layers in the South China Sea: Evidence of contrasting wind directions during eruption ca. 74 ka: Comment and Reply}

\author{
Chang-Hwa Chen, Tsanyao Frank Yang, Sheng-Rong Song, Yoshiyuki lizuka and Kuo-Yen Wei
}

Geology 2000;28;1055-1056

doi: 10.1130/0091-7613(2000)28<1055:TALITS>2.0.CO;2

\section{Email alerting services}

Subscribe

Permission request click www.gsapubs.org/cgi/alerts to receive free e-mail alerts when new articles cite this article

click www.gsapubs.org/subscriptions/ to subscribe to Geology

click http://www.geosociety.org/pubs/copyrt.htm\#gsa to contact GSA

Copyright not claimed on content prepared wholly by U.S. government employees within scope of their employment. Individual scientists are hereby granted permission, without fees or further requests to GSA, to use a single figure, a single table, and/or a brief paragraph of text in subsequent works and to make unlimited copies of items in GSA's journals for noncommercial use in classrooms to further education and science. This file may not be posted to any Web site, but authors may post the abstracts only of their articles on their own or their organization's Web site providing the posting includes a reference to the article's full citation. GSA provides this and other forums for the presentation of diverse opinions and positions by scientists worldwide, regardless of their race, citizenship, gender, religion, or political viewpoint. Opinions presented in this publication do not reflect official positions of the Society.

\section{Notes}

THE 


\section{Toba ash layers in the South China Sea: Evidence of contrasting wind directions during eruption ca. 74 ka: Comment and Reply}

\section{COMMENT}

\section{Chang-Hwa Chen*}

Institute of Earth Sciences, Academia Sinica, P.O. Box 1-55, Nankang,

Taipei, Taiwan

Tsanyao Frank Yang

Sheng-Rong Song

Department of Geology, National Taiwan University, Taipei, Taiwan

Yoshiyuki lizuka

Institute of Earth Sciences, Academia Sinica, P.O. Box 1-55, Nankang,

Taipei, Taiwan

Kuo-Yen Wei

Department of Geology, National Taiwan University, Taipei, Taiwan

Bühring et al. (2000) reported that the ash layers in two cores from the South China Sea dated ca. $74 \mathrm{ka}$ are distinct from the volcanic glass supplied from the Philippines and the northern South China Sea, but are almost identical in terms of the chemical compositions to the Toba ash. They reached this conclusion from the similarities they found in the age and chemical compositions of the glass shards between the tephra layers in their cores and those in the Youngest Toba Tuff eruption.

Studies of the late Quaternary tephra layers in the South China Sea area are quite limited (Chen and Zhou, 1992). Very recently, however, the 17 tephra layers of the International Marine Past Global Change Study

*E-mail: china@earth.sinica.edu.tw
(IMAGES) Core MD972142 from north of Palawan, in the southeastern South China Sea (lat $12^{\circ} 41.33^{\prime} \mathrm{N}$, long $119^{\circ} 27.90^{\prime} \mathrm{E}$ ) at a water depth of $1557 \mathrm{~m}$ have been studied in great detail. The deepest tephra layer (layer 17) in this core was found at the interval 24.01 to $24.08 \mathrm{~m}$, where the major elements of glass are very similar to the related published data for ash layers in Cores 17961-2 and 17962-4 in the South China Sea (Bühring et al., 2000) and in the Toba co-ignimbrite eruptions (Chesner, 1998) (Table 1 and Fig. 1A here). The tephra layer in our Core MD972142 was dated about $0.5 \mathrm{Ma}$, on the basis of its correlation with the major characteristic isotopic events in standard SPECMAP chronology (Chiu et al., 2000). It is well known that there are three major rhyolitic co-ignimbrite eruptions of late Quaternary age in the Toba caldera. The ${ }^{40} \mathrm{Ar} /{ }^{39} \mathrm{Ar}$ age of the Oldest Toba Tuff is $0.84 \pm 0.03 \mathrm{Ma}$, that of the Middle Toba Tuff is $0.501 \pm 0.005 \mathrm{Ma}$, and that of the Youngest Toba Tuff is $74 \pm 2 \mathrm{ka}$ (Chesner and Rose, 1991). In like manner, on the basis of the age and major element composition of glass in ash layer 17 of IMAGES Core MD972142, it can be confirmed that eruption of the Middle Toba Tuff is the most likely origin of this ash layer. Nevertheless, the compositions of the volcanic phenocrysts and isotopic ratios of glass may be more reliable tools for long-distance ash-layer correlations (Haynes et al., 1995). The major element compositions of the biotite crystals and the isotopic fingerprints of glasses in tephra layer 17 were analyzed. The results show that the biotite phenocrysts in layer 17 in Core 972142 have distinctly lower $\mathrm{FeO} / \mathrm{MgO}$ ratios than those of the Middle Toba Tuff (Fig. 1B). Moreover, the ${ }^{87} \mathrm{Sr} /{ }^{86} \mathrm{Sr}$ value of the glass shards is $0.70506 \pm 0.0008$, which is obviously lower than that of the Toba eruptions in Sumatra, Indonesia (0.7128 to 0.7152; Chesner, 1998). The differences

TABLE 1. CHEMICAL COMPOSITIONS OF GLASS IN THE SOUTH CHINA SEA

\begin{tabular}{lcccccccccc}
\hline \hline Core & $\mathrm{SiO}_{2}$ & $\mathrm{Al}_{2} \mathrm{O}_{3}$ & $\mathrm{TiO}_{2}$ & $\mathrm{FeO}$ & $\mathrm{MnO}$ & $\mathrm{MgO}$ & $\mathrm{CaO}$ & $\mathrm{Na}_{2} \mathrm{O}$ & $\mathrm{K}_{2} \mathrm{O}$ & $\mathrm{References}$ \\
\hline $17961-2$ & $78.04 \pm 0.24$ & $12.45 \pm 0.06$ & $0.05 \pm 0.02$ & $0.85 \pm 0.05$ & $0.07 \pm 0.02$ & $0.06 \pm 0.01$ & $0.76 \pm 0.03$ & $2.86 \pm 0.06$ & $4.86 \pm 0.08$ & Bühring et al. (2000) \\
MD972142 & $76.98 \pm 1.13$ & $13.24 \pm 0.29$ & $0.09 \pm 0.05$ & $0.72 \pm 0.11$ & $0.03 \pm 0.01$ & $0.12 \pm 0.04$ & $0.80 \pm 0.25$ & $3.03 \pm 0.35$ & $4.97 \pm 0.25$ & This study \\
\hline
\end{tabular}
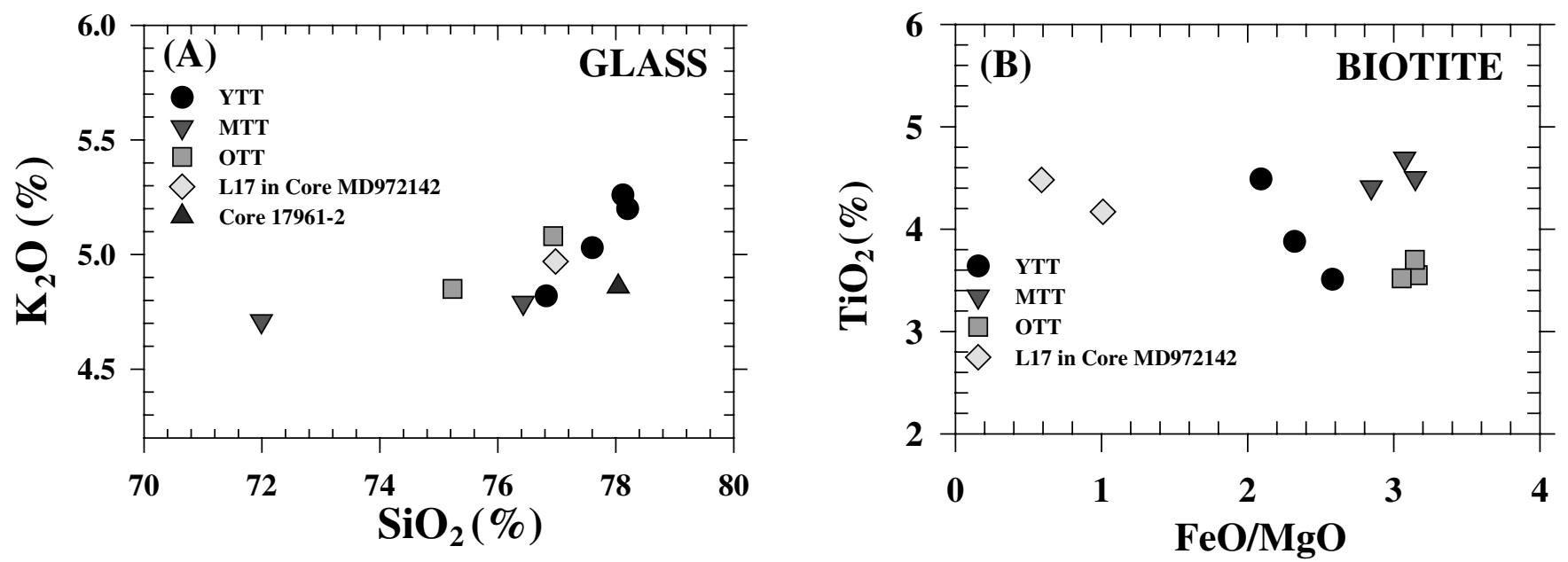

Figure 1. Major element chemical variation diagrams for (A) glasses from Toba eruptions, layer 17 in Core MD972142 and Core $17961-2$ (Bühring et al., 2000), and for (B) biotite grains from Toba eruptions and layer 17 in Core MD972142. All data on Toba eruptions in Sumatra are from Chesner (1998). YTT_-Youngest Toba Tuff; MTT—Middle Toba Tuff; OTT_Oldest Toba Tuff. 
in the isotopic values of glass and phenocryst chemistry demonstrate that they were derived from two compositionally different magma sources.

This evidence strongly suggests that glass and biotite in ash layer 17 do not correlate with the Middle Toba Tuff eruption in northern Sumatra, about $0.5 \mathrm{Ma}$, even though they have similar major element compositions in glass shards. The strong correlation of the ash beds in Core 17961-2 and 17962-4 in the IMAGES study and the Youngest Toba Tuff in the South China Sea indicates that they do not have just the similarities of ages and glass chemistries of the ash layers. Further chemical studies of phenocrysts and isotopes in tephra layers will help to confirm the possibility of alternative ash sources.

\section{REFERENCES CITED}

Bühring, C., Sarnthein, M., and Leg 184 Shipboard Scientific Party, 2000, Toba ash layers in the South China Sea: Evidence of contrasting wind directions during eruption ca. 74 ka: Geology, v. 28, p. 275-278.

Chen, W., and Zhou, F., 1992, A study of volcanic glass in the northern South China Sea during the last $100 \mathrm{ka}$, in Jin, X., et al., eds., Marine geology and geophysics of the South China Sea: Beijing, China Ocean Press, p. 174-178.

Chesner, C.A., 1998, Petrogenesis of the Toba Tuffs, Sumatra, Indonesia: Journal of Petrology, v. 39, p. 397-438.

Chesner, C.A., and Rose, W.I., 1991, Stratigraphy of the Toba Tuffs and the evolution of the Toba Caldera complex, Sumatra, Indonesia: Bulletin of Volcanology, v. 53, p. 343-356.

Chiu, T.C., Wei, K.Y., and Chen, Y.G., 2000, Oxygen isotope stratigraphy of the last 600 thousand years of Core MD972142 in the southeastern South China Sea and its comparison with Chinese loess records: Geological Society of China Annual Meeting, Abstracts, p. 43-45.

Haynes, J.T., Melson, W.G., and Kunk, M.J., 1995, Composition of biotite phenocrysts in Ordovician tephras casts doubt on the proposed trans-Atlantic correlation of the Millbrig K-bentonite (United States) and the Kinnekulle K-bentonite (Sweden): Geology, v. 23, p. 847-850.

\section{REPLY}

\section{Christian Bühring*}

Michael Sarnthein

Institut für Geowissenschaften, Universität Kiel, Olshausenstrasse 40, D-24118 Kiel, Germany

It is interesting to us that Chen et al. in their Comment on our paper (Bühring et al., 2000) do not cite their own recent publication (Song et al., 2000). In that paper, Song et al. reported on an ash layer from the same stratigraphic position as we did, but in another core from the South China Sea, a layer that they likewise identified as Youngest Toba Tuff by microprobe and rare earth element analyses. They thereby confirmed our conclusion based on microprobe analysis (Bühring et al., 2000, published in March 2000, not cited in the paper of Song et al., 2000, published in July).

We do not see any need to reconsider our identification of the Youngest Toba Tuff layer at the MIS 5/4 boundary because of the questions raised by Chen et al., which concern a different, older ash layer, assigned to the Middle Toba Tuff (not discussed in our paper). On the contrary, we thank Chen et al. for their support of our findings.

\section{REFERENCES CITED}

Bühring, C., Sarnthein, M., and Leg 184 Shipboard Scientific Party, 2000, Toba ash layers in the South China Sea: Evidence of contrasting wind directions during eruption ca. 74 ka: Geology, v. 28, p. 275-278.

Song, S.-R., Chen, C.-H., Lee, M.-Y., Yang, T.F., Iizuka, Y., and Wei, K.-Y., 2000, Newly discovered eastern dispersal of the Youngest Toba Tuff: Marine Geology, v. 167, p. 303-312.

*E-mail: cb@gpi.uni-kiel.de.

\section{The GSA Data Repository}

Established in 1974, this is an open file where authors of articles in our journals (and in an occasional book) can place information that supplements and expands on their published article. This supplemental information is not of broad interest and will not appear in print. It may, however, be of interest to select readers and may be obtained by them from GSA.

For each item placed in the Repository, a unique key number* is included at the bottom of the first page on the printed article (e.g., 9201 is entry 1 for 1992). Use this key to order Repository items in either of the ways outlined below:

- Download electronic copies of entries from 1992 forward from our "FTP" site. The files at this site are in Adobe Acrobat format, but each carries a "bin" filename extension (ex: 9201.bin), a step that prevents large files from crashing your PC. Before opening these files in Acrobat, you must rename the "bin" extension to "pdf" (ex: rename 9201.bin to 9201.pdf).

*Occasionally a number may be missing from our lists; in such cases, the number was not used, or the material is otherwise unavailable.
Then you may view these files using an Adobe Acrobat reader for your specific PC (DOS, Windows, Macintosh, or Unix). Acrobat readers are free from Adobe Corporation and other sources. You can also use the more robust Adobe Exchange software, available commercially.

- Order paper copies for any entry (1974 forward) from the GSA Editorial Secretary. Phone 303-447-2020, or e-mail GSA Editorial Secretary (mmayer@geosociety.org). You may also write to GSA Editorial Secretary, P.O. Box 9140, Boulder, Colorado 80301 9140, USA. Be sure to include the reference number(s) for the item(s) wanted.

Each annual edition of GSA Journals on Compact Disc from 1992 forward includes that year's Repository entries, linked to their related journal articles. Annual CD editions may be ordered from GSA Publication Sales: phone (303) 447-2020, ext. 152, fax 303447-1133, or e-mail GSA Publication Sales (pubs@geosociety.org). CDs also may be ordered from the GSA Bookstore on the Web (http://www.geosociety.org/bookstore). 